\title{
Relationship between Exchange Rates and Interest Rates: Case of Albania
}

\author{
Jonada Tafa \\ Epoka University, Research Assistant \\ jtafa@epoka.edu.al
}

\section{Doi:10.5901/mjss.2015.v6n4p163}

\section{Abstract}

This study aims to explain the impact that interest rates have on exchange rate fluctuations. Fluctuations in exchanges can bring large profits, but can also can cause severe loses. Theory suggests that if interest rates on domestic currency increase, then this currency will appreciate against foreign currency. However, this is not always the case, as literature on this topic suggests. To examine this relationship regression analysis is used. Data used in this analysis corresponds to the period from January 2002 until December 2014. This relationship is studied by constructing two models accounting for exchange rate of USD/ALL and EUR/ALL, separately, and their relationship with interest rates. USD to ALL exchange rates and EUR to ALL are the dependent variables in each model, while interest rates on ALL deposits are used as the independent variable for both models. The results show that in the case of Albania, an increase in interest rates of deposits in ALL, caused the exchange rate of ALL/USD to increase, with USD becoming more expensive. While in the case of EUR/ALL exchange rate, it was found that when interest rate in ALL deposits increase, ALL was appreciating against Euro. Therefore, Lek was becoming more expensive.

Keywords: exchange rate; interest rate;

\section{Introduction}

This research aims to examine the relationship that exists among interest rate and exchange rate in Albania. Literature on this topic suggests different views. Based on financial theories, it is widely accepted that an increase in interest rates of domestic currency, will appreciate this currency against other foreign currencies.

The first part of this paper is a review about the exchange rates and its determinants, as stated by financial theories. This section includes previous studies results on the relationship between exchange rate and inflation. It is expected that an increase in inflation would depreciate domestic currency against foreign ones. Then another part included in this section is literature on relationship between exchange rate and interest rate. From financial theory, we expect an appreciation of domestic currency, in case of an increase in domestic interest rates. However, this is not always the case, as it is shown from previous studies. In this part of the paper, it is also discussed on relationship between exchange rate and relative income level, which is widely believed that an increase of income level will cause the domestic currency to depreciate. Among other factors affecting exchange rate movement, government intervention and speculations are discussed.

Last part of this study is an empirical analysis of the impact interest rates have on exchange rate determination. The study takes into account the interest rates on ALL current account deposits and the exchange rates of USD/ALL and EUR/ALL. In the first case, USD resulted to appreciate against ALL when interest rates on ALL deposits increase; while in the second case ALL resulted to appreciate against EUR.

\section{Methodology and Data}

In order to study the impact that interest rates have on exchange rate determination regression analysis is used. First model has a dependent variable exchange rate of USD/ALL and the second model has a dependent variable exchange rate of EUR/ALL. Both models independent variable is interest rate on current accounts in ALL. Data used correspond to the period from January 2002 until December 2014. We have used monthly data so that our model would be more accurate. Data are taken from Bank of Albania, official website. 


\section{Hypothesis}

An increase in interest rates of domestic currency will cause the domestic currency to appreciate against other foreign currencies.

\section{Literature Review}

Exchange rates are of a great concern, especially when dealing with international trade. Changes in exchange rates can give you large profits, but can even cause you great losses. This part of the paper will analyze the relationship between the factors that affect exchange rates in order to make us better understand fluctuations in these rates and what can we do in order to minimize the losses resulting from these fluctuations.

According to theory of "International Finance" (Madura, 2008) factors that influence exchange rate are classified as below:

1. Changes in Inflation

2. Changes in Interest Rates

3. Changes in relative income level between countries

4. Changes in government control

5. Expectations on future exchange rates

\subsection{Changes in Inflation}

Theory suggests that in a country where inflation is high its domestic currency will depreciate. This increase in inflation will increase the demand for foreign goods and decrease the exports, leading to a current account deficit. On the other hand, the exchange rate of the foreign currency will increase, resulting in an appreciation of that currency (Madura, 2008).

One of the most widely accepted theories explaining the relationship between inflation and exchange rates is Purchasing Power Parity. This theory states that a basket of goods in one country should have the same cost in another country, taking into account exchange rates.

Different authors have studied the relationship that exists among inflation and exchange rates.

According to Bleaney (1996) there exists a strong positive correlation between exchange rate and inflation. $\mathrm{He}$ stated that the present value of any investment opportunity depends on expected demand, price level and relative prices. Since relative prices movements are not certain this uncertainty effects investment decision as well. In a study of a sample of 41 developing countries from year 1980 until 1990, he found a negative link between exchange rates, real ones and growth, and a direct relationship between exchange rates and inflation.

Inflation in home country is one a very important factor that may lead to currency depreciation as stated by Sodersten and Reed (1994).

Oriavwote and Eshenake (2012) in a study of the relationship among Real Exchange Rates and Inflation rate in Nigeria, found that exchange rates are very sensitive to changes from of inflation and import. Data for this study corresponded to the period from 1970 to 2010, in the state of Nigeria. In their research they state that governments should not rely on inflation targeting if they want to stabilize exchange rates.

As exchange rate fluctuations result mostly by changes in inflation, controlling the exchange rate would be inefficient in case there is inflation. Because of this relationship when deciding on monetary policy both inflation and exchange rates should be considered as interconnected targets (Ahmad \& Ali, 1999).

\subsection{Changes in relative income level between countries}

Financial theory suggests that when the income level of the domestic country increases, people would tend to buy and invest more in the foreign country. This would result in current account deficits, as a result of higher imports. A negative current account is equivalent with currency depreciation.

Several studies have been made to find a link between income differential and exchange rate differential.

To understand the effect of income level on exchange rates Khan (2010) conducted a simple linear regression model, taking data from two countries USA and Pakistan. From the regression estimates it was seen that the effect of income differential on exchange rate differential between these two countries was very small, with a $R^{2}=38,40 \%$. However, the study found a positive relationship between these two variables. An increase in income level would result in 
an increase in exchange rate as well.

\subsection{Changes in government control}

Government can affect exchange rate equilibrium through:

1. Exchange Barriers

2. Trade Barriers

3. Buying/Selling currency in exchange market

4. Intervening in inflation, interest rates and income level.

Governments through their central banks intervene in exchange rates for three main reasons (Madura, 2008) :

1. To flat fluctuations in exchange rates

2. To set up exchange rate boundaries

3. To react to temporary disturbances

\subsection{Expectations on future exchange rates}

Like the other financial markets, even exchange market reacts in case there is any news about the future. In case there is a signal about a probable high inflation in the future, it may cause currency traders to sell the currency, whose home country inflation rate is expected to increase. This puts a downward pressure on that currency, leading to a deprecation of the currency.

Speculations about future exchange rates are mostly driven by changes in interest rates. There have been conducted several studies about the relationship between exchange rates and expectations on future exchange rates or the so-called speculations.

According to Carlson and Osler (1998), the effect of speculations on exchange rates depends on the type of the shocks present in the market. Changes in liquidity of demand do not straightforwardly affect portfolio decisions of the speculators. Increases in speculations would lessen the exchange rate impact on these shocks. On the other hand, changes in interest rates or risk do affect directly speculators portfolio positions. A larger number of speculators in the market, the total reaction to these shocks will increase, thus exchange rate responses to these changes are higher.

\subsection{Changes in Interest Rates}

Interest rates, together with inflation rate, are among the most significant factors affecting exchange rate fluctuations. An increase in the interest rate of the home currency will increase the number of home currency deposits. A higher interest rate means higher rates of return, thus the demand for home currency will increases. These situations lead to an appreciation of home currency relative to foreign currency.

In 1986 Federal Reserve Bank of Kansas City made a study to examine the relationship between interest rates and exchange rates in USA form 1974 to 1986. From the analysis, it was observed a negative relationship between exchange rates and interest rates, which came as the result of the inflation shock during this period. On the other hand, during 1980s it was observed a positive correlation between interest rates and dollar price (Hakkio, 1996) .

By using Vector Autoregression model Goldfaijn and Baig (1998) conducted a research aiming to find a relationship between real interest rate and real exchange rate. The sample was comprised by data about daily interest rates and exchange rates from July 1997-1998 in Asian countries. The results of the regression model did not show a strong relationship between these two rates.

Goldfajn and Gupta (1999) studied the linkage between exchange rates and interest rates in the international area and found that an increase in interest rates will result in an appreciation of nominal exchanges rates. Their study was based on 80 currency crises from 1980 until 1998.

On the other hand Furman and Stiglitz (1998) from their study in 9 developing countries during 1992-1998, stated that an increase in interest rates would result in a deprecation of nominal exchange rates. However, this result is more prominent in countries with low inflation than in countries with high inflation.

\section{Exchange Rates in Albania}

Albania is a transition country, which aspires to join European Union. It has gone through numerous reforms to be ready to be part of the Union. Albania received candidate country status on 24 June 2014. It is located in west Balkan near 
euro area. Process of transition begun in 1990 where prices and free trade were liberalized.

Until 1990 Albania was using a fixed exchange rate regime. Then, in July 1992 exchange rate regime changed from a fixed exchange rate to flexible exchange rate. This change came as a result of low level of foreign reserves, which are a must if a fixed exchange system is going to be implemented. Even though Albania is using a floating exchange rate government through Bank of Albania occasionally intervenes in the foreign exchange market in order to flat temporary fluctuations and to collect needed reserves.

After 2000, in exchange rate market a significant euro was appreciating against lek, while USD was devaluating against lek.

Figure 1: USD/ALL Exchange rates, Jan 2002-Dec 2014

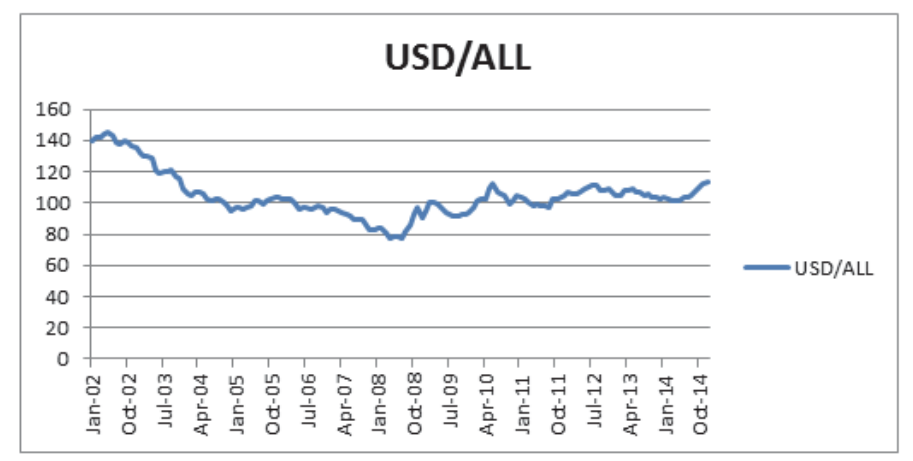

Source: Bank of Albania

Interpreting data from Figure1, we observe that the highest USD/ALL exchange rate was observed in May 2002, when USD/ALL= 144.91. From May 2002 until January 2005 we can see that Lek was continuously appreciating against USD, thus Lek was becoming more expensive. Then from January 2005 until October 2005 USD/ALL performed a slight increase, leading ALL to slightly depreciate. After this moment until mid of 2008 ALL was again appreciating against USD, with USD/ALL continuously decreasing. In the last part of 2008 we experienced a sharp increase of USD/ALL exchange rate, thus with ALL depreciating against USD. During 2014 a increasing trend of USD/ALL exchange rate was observed, meaning that ALL was depreciating against USD. It was now becoming more expensive to buy USD.

Figure 2: EUR/ALL Exchange Rates, Jan 2002- December 2014

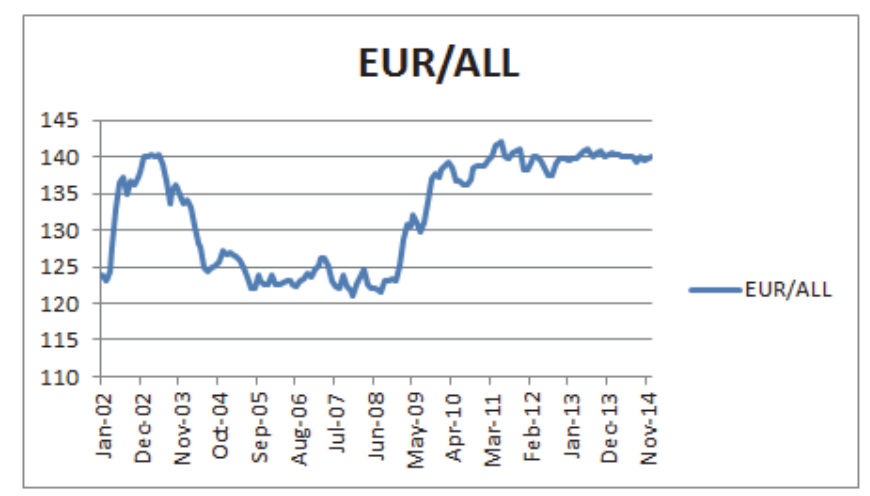

Source: Bank of Albania

Regarding EUR/ALL exchange rate, we can see, referring to Figure 2, that it has been more fluctuated compared to that of USD/ALL. From May 2003 until August 2004 ALL was continuously appreciating against Euro. Then following this period until 2007 this exchange rate has been relatively stable. After the beginning of the financial crisis of 2008 till January 2010, ALL has been relatively appreciating against EURO. ALL was becoming more expensive compared to 
Euro. Then, from 2012 until the end of 2014, these exchange rates have been relatively stable, with a slight appreciation of ALL in mid 2014.

5.1 Interest Rates in ALL

Figure 3: Interest Rates in 12 months ALL Deposits

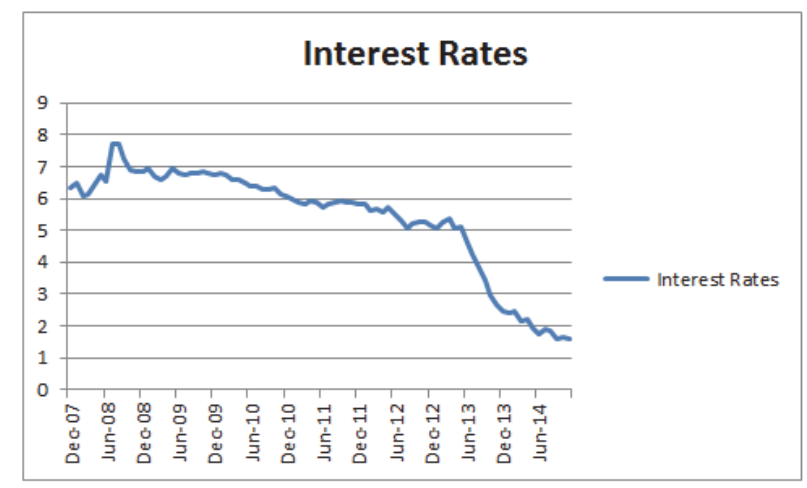

Source: Bank of Albania

\subsection{Deposits in ALL}

Figure 4: 12 Month Deposits in ALL

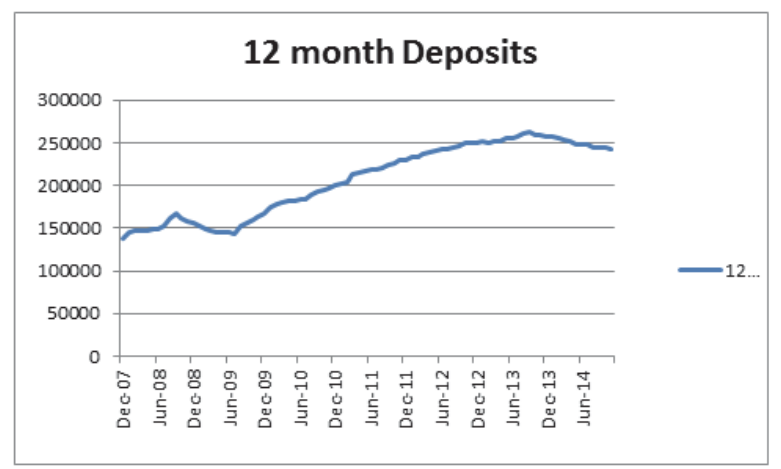

Source: Bank of Albania

From the theory, we expect that an increase in interest rates in ALL, deposits in ALL would increase also. However, this does not seem to be always the case of Albania. From Figures $3 \& 4$ we see that from December 2009 till June-July 2012, when the interest rates in All have been decreasing, deposits in ALL have been increasing which rejects our hypothesis that an increase in interest rates increases deposits in that currency. This period corresponds to the beginning of the last financial crises. During this period faith on USD or EURO was falling and this may be one of the reasons of the increase in ALL deposits.

\section{Results and Discussion}

In the following section, this study will make an analysis of the relationship of the exchange rates of USD and EURO to ALL from January 2002 until December 2014 with interest rates in Albania. 
Figure 5: Regression Output USD/ALL and ALL Interest rate

\begin{tabular}{|c|c|c|c|c|}
\hline \multicolumn{5}{|c|}{$\begin{array}{l}\text { Dependent Variable: USD_ALL } \\
\text { Method: Least Squares } \\
\text { Date: 02/10/15 Time: 09:35 } \\
\text { Sample (adjusted): } 1155 \\
\text { Included observations: } 155 \text { after adjustments }\end{array}$} \\
\hline Variable & Coefficient & Std. Error & t-Statistic & Prob. \\
\hline ALL_INT_RATE & $\begin{array}{l}20.45522 \\
95.02005\end{array}$ & $\begin{array}{l}1.718925 \\
1.130727\end{array}$ & $\begin{array}{l}11.90001 \\
84.03447\end{array}$ & $\begin{array}{l}0.0000 \\
0.0000\end{array}$ \\
\hline $\begin{array}{l}\text { R-squared } \\
\text { Adjusted R-squared } \\
\text { S.E. of regression } \\
\text { Sum squared resid } \\
\text { Log likelihood } \\
\text { F-statistic } \\
\text { Prob(F-statistic) }\end{array}$ & $\begin{array}{r}0.480670 \\
0.477275 \\
10.22777 \\
16004.92 \\
-579.3205 \\
141.6101 \\
0.000000\end{array}$ & \multicolumn{2}{|c|}{$\begin{array}{l}\text { Mean dependent var } \\
\text { S.D. dependent var } \\
\text { Akaike info criterion } \\
\text { Schwarz criterion } \\
\text { Hannan-Quinn criter. } \\
\text { Durbin-Watson stat }\end{array}$} & $\begin{array}{l}104.2658 \\
14.14636 \\
7.500910 \\
7.540180 \\
7.516861 \\
0.080559\end{array}$ \\
\hline
\end{tabular}

From the output of Table 1 by using $R^{2}$ value we can measure the goodness of fitness. In this model $R^{2}=0.48$, implying that $48 \%$ of variation in exchange rates is explained by the variation in interest rates. If we observe the value of Adjusted $\mathrm{R}^{2}(0.477)$ we can see that its value its very close to $\mathrm{R}^{2}$. This implies that over fitting problem is almost not present in this model, which is a good indicator of the accuracy of the model.

An important consideration in performing this kind of analysis is the testing whether the model is statistically significant or not. For the model to be statistically significant Sig. or probability of F-statistics ( $p$ ) should be less or equal to the level of significance. In this model significance level is 0.05 and $p$ (F-stat) is 0.000 , thus model is statistically significant.

From Table 1 we can get the data to construct a regression model explaining the relationship between exchange rate and interest rates.

$$
E\left(\frac{U S D}{A L L}\right)=95.02+20.45 * \text { Int. Rate }+u
$$

\subsection{Equation 1: Estimated Regression Model USD/ALL and ALL Interest Rates}

After finding that the model is statistically significant, significance of coefficients with the dependent variable is measured. The following paragraph explains how the significance of betas is tested.

To test whether coefficients are significant or not, the following hypothesis are used:

- $H_{0}: \beta=0$

- $H_{1}: \beta \neq 0$

These hypothesis test if the explanatory variables have a statistically significant effect on the explained variable or not. If the probability of the t-statistic of the coefficient is less than or equal to confidence level, null hypothesis is rejected, which means that the coefficients are statistically significant. In this model significance level is 0.05 .

Both intercept and coefficient of interest rates are statistically significant. $\mathrm{P}(\mathrm{t}$-statistic) of the intercept is 0.0000 , which is smaller than significance level of 0.05 . Even the $\mathrm{P}(\mathrm{t}$-statistics ) of interest rate is smaller than significance level.

From the results of Equation 1, we can explain the link between exchange rate and interest rate. $B$ of the independent variable is 20.45 . Mathematically this result shows that with one percent increase in interest rates will increase exchange rates by 20.45 units. On economic term, this means that even when interest rates of deposits in Lek were increasing, Albanian Lek was not appreciating, but instead depreciating against USD, because USD was gaining value. As we have mentioned before, we wanted to test that when interest rates on domestic currencies increases, this currency would depreciate against the foreign currencies. However, this seems not to be the case of Albania, as Lek in our case proved to depreciate against US Dollar. A logical explanation behind this may be that interest rate is not the only factor that affects changes in exchange rates. As we have stated in our literature review there are other factors such as inflation rate, relative income level, government control and future expectations in exchange rates that affect exchange rate movements. Another reason may the economical and political instability of Albania. Even after 24 years since the moment country abounded communist system, it is still in its transition phase. The levels of informal economy and corruption are relatively very high.

Now in this part we want to test whether our hypothesis proves to be true in the relationship between EUR/ALL 
exchange rate and ALL interest rates.

Figure 6: Regression Output EUR/ALL and ALL Interest rate

\begin{tabular}{|c|c|c|c|c|}
\hline \multicolumn{5}{|c|}{$\begin{array}{l}\text { Dependent Variable: EUR_ALL } \\
\text { Method: Least Squares } \\
\text { Date: 02/10/15 Time: } 09: 36 \\
\text { Sample (adjusted): } 1155 \\
\text { Included observations: } 155 \text { after adjustments }\end{array}$} \\
\hline Variable & Coefficient & Std. Error & t-Statistic & Prob. \\
\hline ALL_INT_RATE & $\begin{array}{r}-0.870581 \\
132.7041\end{array}$ & $\begin{array}{l}1.237645 \\
0.814136\end{array}$ & $\begin{array}{r}-0.703417 \\
162.9998\end{array}$ & $\begin{array}{l}0.4829 \\
0.0000\end{array}$ \\
\hline $\begin{array}{l}\text { R-squared } \\
\text { Adjusted R-squared } \\
\text { S.E. of regression } \\
\text { Sum squared resid } \\
\text { Log likelihood } \\
\text { F-statistic } \\
\text { Prob(F-statistic) }\end{array}$ & $\begin{array}{r}0.003224 \\
-0.003291 \\
7.364113 \\
8297.215 \\
-528.4049 \\
0.494796 \\
0.482865\end{array}$ & \multicolumn{2}{|c|}{$\begin{array}{l}\text { Mean dependent var } \\
\text { S.D. dependent var } \\
\text { Akaike info criterion } \\
\text { Schwarz criterion } \\
\text { Hannan-Quinn criter. } \\
\text { Durbin-Watson stat }\end{array}$} & $\begin{array}{l}132.3106 \\
7.352024 \\
6.843934 \\
6.883204 \\
6.859884 \\
0.029060\end{array}$ \\
\hline
\end{tabular}

First of all is worth mentioning that as seen from Prob( F-statistic) value referring to Figure 4, this model is statistically insignificant. $R^{2}$ is very small and there is a great change between $R^{2}$ and Adjusted $R^{2}$, meaning the over-fitting in this model is not mitigated. Regarding the significance of constant c coefficient, we see that it statistically significant, but beta coefficient of ALL interest rates is not statistically significant.

However, from the data from Figure 4, we can observe the following regression equation.

EUR_ALL $=132.70408337-0.87058125031^{*} A L L I N T \_R A T E$

\subsection{Equation 2: Estimated Regression Model EUR_ALL and ALL Interest Rates}

From equation 2, we can estimate that one percent increase in ALL interest rate will decrease EUR/ALL exchange rate by 0.87 points. This means that when interest rate on ALL increases, ALL seems to appreciate against Euro. In this case, our hypothesis stating that an increase in interest rate of domestic currency increases that currency will appreciate resulted to be true. However, it is worth mentioning that the model is statistically insignificant. This insignificance can be explained by events that have happened with EU member countries, such as Greece and Portugal.

\section{Conclusion}

This research was mainly concerned on defining the impact that interest rates have had on exchange rate determination in Albania. It was firstly analyzed based on previous studies, the determinants of exchange rates as explained by the financial theories. The last part of the paper was an empirical analysis of the relationship among exchange rate and interests in Albania from January 2002 until December 2014. Exchange rates used were USD/ALL and EUR/ALL, while interest rates were the interest rates of ALL. From the regression analysis, it resulted that an increase in interest rate of ALL deposits would result in an increase of exchange rate of ALL/USD. From the financial background it was expected the opposite, but a logical explanation behind this, is that exchange rate are also affected from other factors such as inflation rate, income level, government control, speculations on future exchange rates and many other external factors. Regarding the relation between EUR/ALL exchange rate and interest rate on ALL deposits, it seems that our hypothesis is true. However, we should keep in mind that the model resulted to be statistically insignificant. This shows that fluctuations of Euro have been affected not only from changes in interest rate, but even from other factors too, such as the crisis in Greece, a member of EU and a country which uses Euro as domestic currency.

\section{References}

Ahmad, E., \& Ali, S. (1999). Relationship between Exchange Rate and Inflation. Pakistan Economic and Social Review , $139-154$.

Bank of Albania. (n.d.). Retrieved 01 25, 2015, from http://www.bankofalbania.org/web/Time_series_22_2.php?evn=periudha\&evb=agre gate \&periudha=1

Bleaney, M. (1996). Macroeconomic Stability, Investment and Growth in Developing Countries. Journal of Development Economics , 461-477.

Carlson, J., \& Osler, C. (1998). Rational Speculators and Exchange Rate Volatility. Federal Reserve Bank Of New York . 
Furman, J., \& Stiglitz, J. E. (1998). Economic Crises:Evidence and Insights from East Asia. Brooking Papers on Economic Activity , Washington D.C.

Goldfajn, I., \& Baig, T. (1998). Monetary Policy in the Aftermath of Currency Crises: The case of Asia. International Monetary Fund Working Paper.

Goldfajn, I., \& Gupta, P. (1999). Does Monetary Policy Stabilize the Exchange Rate Following a Currency Crisis? International Monetary Fund Working Paper.

Hakkio, C. (1996). Interest Rates and Exchange Rates-What is the Relationship? Economic Review , 33-43.

Khan, M. (2010). Impact of Per Capita Income on Exchange Rate with Regression Tool. Social Science Research Network .

Madura, J. (2008). International Financial Management. NA: Thomson Southwestern.

Oriavwote, V., \& Eshenake, S. (2012). Real Exchange Rate and Inflation: An Empirical Assessment of the Nigerian Experience. Mediterranean Journal of Social Sciences.

Sodersten, B., \& Reed, G. (1994). Macroeconomic Policy with Fixed and Pegged Exchange Rates. In B. Sodersten, \& G. Reed, International Economics, Third Edition (pp. 631-641). Houndmills, Basingstoke: The MacMillan Press Ltd. 